\title{
Maternal Intake Restriction Programs the PKA-CREB Pathway to Regulate Energy Metabolism, CLOCK and mTOR Signals in the Skeletal Muscles of Goat Offspring
}

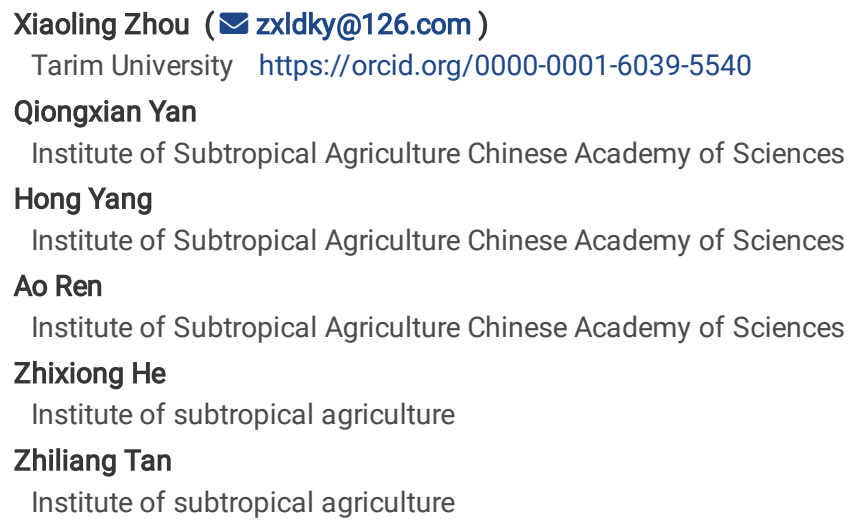




\section{Abstract}

\section{Background}

The biological mechanism about that maternal undernutrition increases the metabolic disorder risk of skeletal muscles in offspring is less known. We hypothesize that maternal intake restriction influences metabolic signals in the skeletal muscles of offspring via a glucagon-mediated pathway. Twentyfour pregnant goats were assigned to the control ( $100 \%$ of the nutrients requirement) and restricted ( $60 \%$ of the control from pregnant days of 45 to 100$)$ groups. Blood and longissimus thoracis muscle were sampled from dams, fetuses and kids in each group.

\section{Results}

Intake restriction reduced the total blood protein of dams and fetuses. Maternal restriction decreased the $C R E B 1, C R E B B P, P K A, B M A L 1, A K T 1, m T O R$, and RPTOR mRNA expressions in the fetuses, reduced the CREBBP, NR1H3, DBP and PKA mRNA levels in the kids, but increased the PGC1a and TSC2 mRNA levels in the fetuses, while the mRNA expression of CLOCK and TSC2 genes was increased in the restricted kids. The protein expression of total PKA and phosphorylated PKA of the restricted fetuses and kids were downregulated, while the protein expression of total mTOR and phosphorylated mTOR were reduced in the restricted fetuses and kids.

\section{Conclusions}

Maternal intake restriction regulated fat oxidation, protein synthesis, and circadian clock expression in the muscles of the offspring via the glucagonmediated PKA-CREB pathway, which reveals a molecular pathway that maternal undernutrition leads to metabolic adaptation of skeletal muscle in offspring.

\section{Background}

Maternal protein-energy malnutrition often induces a high metabolic risk in offspring $(1,2)$. Skeletal muscle accounts for $40 \%$ of the body's weight and is one of the key tissues for metabolic regulation (3). Maternal undernutrition alters skeletal muscle development by reducing the cell number (muscle fibers), the muscle protein synthesis and degradation rates, and the muscle fiber type composition and proportion (4-7). These alterations affect the metabolic characteristics of skeletal muscle, including insulin sensitivity, glucose transport, uptake, storage and aerobic utilization, and lipid accumulation (3, 8). The affected offspring are susceptible to imbalance of energy metabolism, insulin resistance, or lipid metabolism disorders in skeletal muscle (9, 10).

Muscular energy metabolism is adjusted by molecular signaling pathways network. The mTOR pathway is an evolutionarily conserved regulator of cell growth and proliferation that controls intracellular protein anabolism and inhibits protein degradation (11). It is also one of the central modulators during skeletal muscle development (12). The AMPK pathway is in charge of muscle energy sensing and homeostasis $(13,14)$. Moreover, the AMPK pathway is linked to the mTOR pathway via intracellular nutritional signals. One of the signals is ATP availability, and AMPK is activated by an increased intracellular AMP/ATP ratio; the activated AMPK phosphorylates and activates TSC1/TSC2 dimers to inhibit mTORC1 (15), thereby coupling the processes of energy sensing and protein synthesis at the cellular level under energy-deficient condition. Additionally, the rhythmic timing system, including a central clock in the hypothalamic nucleus and peripheral tissue clocks in the liver, muscle and adipose tissue, responds to central and peripheral timing factors such as endocrine hormones, neural signals, eating patterns, body temperature, oxygen, light-dark cycles and sleep-wake signals (16). At the tissue level, the circadian clock integrates intracellular and extracellular signals (such as nutrient levels) to modulate energy homeostasis and protein synthesis (17, 18), and metabolic rhythm disorders are associated with metabolic abnormalities and diseases(19).

Blood metabolites, amino acids and hormone secretion reflect the nutritional status of whole body, which were changed in the pregnant goats and offspring exposed to late-gestational undernutrition (20). The independent effects of maternal malnutrition on the mTOR signaling (21, 22) and AMPK pathways $(21,23,24)$ in the skeletal muscles of mammals in vivo and vitro, and on the central circadian clock in rats $(25,26)$ have been reported. However, knowledge about the association of maternal undernutrition with the energy metabolism, protein synthesis, and disruption of the metabolic rhythms of skeletal muscle in offspring is still unknown.

Previously, we have noticed an association of an elevated glucagon level in mother goats caused by maternal intake restriction during midgestation with a programed liver energy metabolism in the offspring (27) and a reduction in the muscle mass in the kid goats (28). Glucagon influences tissue metabolism through the classical CAMP-PKA-CREB pathway in peripheral tissues (29), and CREB is a key regulator in energy metabolism (30), protein synthesis and circadian control $(31,32)$. To test the hypothesis that whether maternal intake restriction programs the PKA-CREB pathway of the skeletal muscle in the offspring to affect metabolic signals, we investigated the effects of $40 \%$ maternal intake restriction during midgestation on the concentrations of blood metabolites, muscular cAMP and glycogen, and on the expression of genes involved in the mTOR, AMPK and CLOCK pathways. The findings will give new insights into understanding the metabolic adaptation caused by maternal undernutrition in humans.

\section{Materials And Methods}

\section{Experimental design and animal management}

All the protocols used in this study were approved by the Animal Care Committee according to the Animal Care and the Use Guidelines of the Institute of Subtropical Agriculture, Chinese Academy of Sciences, Changsha, China (No. KYNEAAM-2015-0009). Twenty-four goats (45 \pm 3 d of gestation, Liuyang 
black goat, local breed) were selected and randomly assigned to a control [C, $100 \%$ of the nutrients requirement suggested in the feeding standard of meat-producing sheep and goats of China (2004), $n=12$ ] or a feed intake-restricted (, $60 \%$ of the control, $n=12)$ group. The restriction period was from 45 to $100 \mathrm{~d}$ of gestation. The dam weight, animal management and diet composition were the same as those in our previous study (27). At $100 \mathrm{~d}$ of gestation, after examination with ultrasonography (Aloka SSD-500 with a 5-MHzlinear probe Aloka, Shanghai, China), six dams from each group were randomly chosen for slaughtering, and the samples from dams and their fetuses were collected. The remaining dams were realimented to $100 \%$ of nutrients requirement after $101 \mathrm{~d}$ of pregnancy. After delivery, the newborn goats were naturally breastfed until $50 \mathrm{~d}$ postpartum. Between 50 and $60 \mathrm{~d}$ of age, the kids were preweaned. After complete weaning at $60 \mathrm{~d}$ of age, the diet containing milk replacer and fresh grass was given until $90 \mathrm{~d}$ of age. The management measures and diet composition for kids were described previously (28). At $90 \mathrm{~d}$ of age, sixteen kids (8 of each group) were slaughtered and samples were collected.

\section{Blood and tissue sampling}

After fasting overnight, the dams and kids were electrically shocked, and blood was collected from the jugular veins. Plasma was anticoagulated with heparin sodium and separated through centrifugation at $1200 \times \mathrm{g}$ for $10 \mathrm{~min}$ at $4^{\circ} \mathrm{C}$ and stored at $-80^{\circ} \mathrm{C}$ for subsequent analysis. Following exsanguination and ventrotomy of the dams, fetal blood samples were collected from the umbilical cord, and the plasma was separated as described above. The hot carcass weight of animals were weighed after removal of the skin, head, hoofs, tail and visceral organs except kidneys, and samples of the longissimus thoracis (LT) muscle between the $5^{\text {th }}$ and $8^{\text {th }}$ ribs were sliced and snap-frozen in liquid nitrogen and then stored at $-80^{\circ} \mathrm{C}$ until further analysis.

\section{Blood biochemical parameters and free amino acid (AA) analysis}

After plasma samples were thawed at $4^{\circ} \mathrm{C}$, the total protein (TP) concentration was determined using assay kits (Beijing Leadman Biochemistry Company Limited, Beijing, China) with an automatic biochemical analyser (Hitachi 7600, Hitachi, Ltd., Tokyo, Japan). The concentrations of non-esterified fatty acid (NEFA) were measured using assay kits (Nanjing SenBeiJia Biological Technology Co., Ltd., Nanjing, China). The concentrations of triiodothyronine (T3) and thyroxine (T4) were measured using an enzyme-linked immunosorbent assay according to the manufacturer's instructions (Cusabio Biotech Company Limited, Wuhan, China). The intra- and inter-assay coefficient variations of T3 and T4 were all below $10 \%$.

The analysis of free AAs in blood was determined as described earlier (33). Briefly, $500 \mu \mathrm{L}$ of plasma sample was taken and mixed with $500 \mu \mathrm{L}$ of 0.30 $\mathrm{mol} / \mathrm{L}$ sulfosalicylic acid solution. The mixed solution was placed at $4^{\circ} \mathrm{C}$ overnight and centrifuged at $10000 \times g$ for 10 min at $4^{\circ} \mathrm{C}$. The supernatant was collected and filtrated using a $0.22 \mu \mathrm{m}$ microporous membrane. The filtrate was measured using an L-8800 automatic amino acid analyser (L-8800, Hitachi, Tokyo, Japan).

\section{Glycogen and cAMP determination}

The glycogen (Nanjing Jiancheng Bioengineering Research Institute, Nanjing, China) and cAMP (NewEast Biosciences, Malvern, USA) in the LT muscle were determined according to the manufacturer's instructions. The preparation procedure was performed as previously described (27), and the results were expressed as $\mathrm{mg} / \mathrm{g}$ protein in the fresh tissue.

\section{Quantitative RT-PCR}

The total RNA of sample was extracted using precooled TriQuick Reagent (Solarbio, Beijing, China) according to the manufacturer's instructions. The expression of the target mRNAs was analysed using the SYBR green method with a LightCyclerß 480 system (Roche Applied Science, Basel, Switzerland), and the detailed method was described previously (27). The specific gene primers are listed in Table 1. Relative gene expression levels were normalized to the levels of the reference gene ACTG1 using the 2- $\Delta \Delta \mathrm{Ct}$ method (34), where $\mathrm{Ct}$ denoted the threshold cycle. 
Table 1

Gene-specific primers for RT-qPCR

\begin{tabular}{|c|c|c|c|}
\hline Gene & Primer Sequence $\left(5^{\prime}-3^{\prime}\right)^{1}$ & Amplicon size (bp) & Accession number \\
\hline \multicolumn{4}{|c|}{ Energy metabolism } \\
\hline \multirow[t]{2}{*}{$A C A C A$} & F: ATGTGGATGATGGGCTGAA & 139 & XM_018064168.1 \\
\hline & R: GCTTGAACCTGTCGGAAGAG & & \\
\hline \multirow[t]{2}{*}{$\operatorname{ACOX} 1$} & F: ACCTGTGAGTTTGTGCCTGA & 109 & XM_018063769.1 \\
\hline & R: TTGGGCTGGAAAGATGCTAC & & \\
\hline \multirow[t]{2}{*}{ CPT1A } & F: TCATACTCGCTGGGAACAGA & 111 & XM_018043311.1 \\
\hline & R: TCTCGGAAGGAAACAAATGC & & \\
\hline \multirow[t]{2}{*}{ CREB1 } & F: TTGTGGTTTTTCCTAGGTGTGT & 115 & XM_005676432.3 \\
\hline & R: GTTTTCTGCTGCTGTGCAAC & & \\
\hline \multirow[t]{2}{*}{ CREBBP } & F: GAATGGATCTCTCGGGGCTG & 119 & XM_018040244.1 \\
\hline & R: GCGGTGAAACTTGGGTCAAC & & \\
\hline \multirow[t]{2}{*}{ G6PDH } & F: ACCTATGGCAACCGATACAAGA & 144 & XM_018044343.1 \\
\hline & R: GTGGAGCAGTGGAGTGAAGAT & & \\
\hline \multirow[t]{2}{*}{ INSR } & F: TCAAGGACGGAGTCTTCACC & 119 & XM_018051134.1 \\
\hline & R: TTTCAGCACCTGCTCATTTG & & \\
\hline \multirow[t]{2}{*}{ NR1H3 } & F: TGCTGATGAAACTGGTGAGC & 147 & NM_001285751.1 \\
\hline & R: TGAAGACACGGAGGAGGAAC & & \\
\hline \multirow[t]{2}{*}{$G R$} & F: AGAGGGAGAGGGAAATGGAG & 121 & XM_018050198.1 \\
\hline & R: TTGGAATGAGAAGGGTGGTC & & \\
\hline \multirow[t]{2}{*}{ PCK1 } & F: GCGTTCAACGTCCGATTTCC & 105 & XM_005688314.3 \\
\hline & R: CTCGATGCCGATCTTGGACA & & \\
\hline \multirow[t]{2}{*}{ PCK2 } & F: TACGTGCTTCCGTTCAGCAT & 177 & XM_018054616.1 \\
\hline & R: TTGGCCCACAGAGTGAAGAC & & \\
\hline \multirow[t]{2}{*}{ PKA } & F: ATTGTCTCTGGGAAGGTGCG & 80 & XM_018051193.1 \\
\hline & R: TCCACTTGTAGGAGGTTGCG & & \\
\hline \multirow[t]{2}{*}{ PRKAA2 } & F: TTGATGATGAGGTGGTGGAG & 138 & XM_018044652.1 \\
\hline & R: CCGTGAGAGAGCCAGAGAGT & & \\
\hline \multirow[t]{2}{*}{ PRKAB1 } & F: CCАССАСАТСТССТССААGT & 135 & XM_013970630.2 \\
\hline & R: GAGCACCATCACTCCАTCCT & & \\
\hline \multirow[t]{2}{*}{ PGC1A } & F: CCGAGAATTCATGGAGCAAT & 184 & XM_018049155.1 \\
\hline & R: GATTGTGTGTGGGCCTTCTT & & \\
\hline \multirow[t]{2}{*}{ STK11 } & F: GGACACCTTCTCTGGCTTCA & 126 & XM_018050463.1 \\
\hline & R: CCCTTCCCGATGTTCTCAA & & \\
\hline \multicolumn{4}{|c|}{ Circadian signaling } \\
\hline \multirow[t]{2}{*}{$B M A L 1$} & F: GCACGGCGTTCTTTCTTCTG & 115 & XM_018059578.1 \\
\hline & R: TGCAGAAGCTTTTTCGATCTGC & & \\
\hline \multirow[t]{2}{*}{ CLOCK } & F: GGGTAAAAGTCAAAGCCACCC & 98 & XM_018049467.1 \\
\hline & R: ACCGGTTACTGGAAAGCAGG & & \\
\hline \multirow[t]{2}{*}{ CRY1 } & F: CTGGTCTTGGCAGTGGGAAA & 106 & XM_013964057.2 \\
\hline & R: ACCAAAGCTCTССТССТTACСT & & \\
\hline$C R Y 2$ & F: AAAGGGTTCCCСTCTCGGTA & 149 & XM_018059193.1 \\
\hline
\end{tabular}

Page $4 / 16$ 


\begin{tabular}{|c|c|c|c|}
\hline & R: TGCTTCATCCGCTCGATGTT & & \\
\hline \multirow[t]{2}{*}{$D B P$} & F: GATACGGTGGAGGTGCTGAT & 91 & XM_018062728.1 \\
\hline & R: TCCGAGGGTCAAAGGTCTC & & \\
\hline \multirow[t]{2}{*}{ PER1 } & F: ACCTGGAGAAGAGAAGTACCCT & 96 & XM_018064611.1 \\
\hline & R: GAGGGCTGAGAAGTTTGACCA & & \\
\hline \multirow[t]{2}{*}{ PER2 } & F: GACTGGTTAGGACGCGGCTC & 150 & XM_018040197.1 \\
\hline & R: CCACTGCTCATGTCCACGTC & & \\
\hline \multicolumn{4}{|c|}{ mTOR signaling } \\
\hline \multirow[t]{2}{*}{$A K T 1$} & F: TTCAAGCCTCAGGTCACGTC & 101 & NM_001285750.1 \\
\hline & R: ATGCTGTCGTCTTGGTCAGG & & \\
\hline \multirow[t]{2}{*}{ mTOR } & F: CATCACCCTTGCTCTCCGAA & 116 & NM_001285748.1 \\
\hline & R: TACGGATCTCCTTGTGCTCG & & \\
\hline \multirow[t]{2}{*}{ RPTOR } & F: CATTAGTCCCCAGACCAGACG & 128 & XM_018063632.1 \\
\hline & R: CACCTCCATCTGTCCTTCGC & & \\
\hline \multirow[t]{2}{*}{ TSC1 } & F: CAGACAACCCCATGTTCCGA & 107 & NM_001314283.1 \\
\hline & R: CAGAAGCCAGGTCGCCTAAA & & \\
\hline \multirow[t]{2}{*}{ TSC2 } & F: GTCTCAACGAGAGGCCCAAG & 178 & NM_001285553.1 \\
\hline & R: GGGACTGCCGTGAAATTGGA & & \\
\hline \multirow[t]{2}{*}{ ACTG1 } & F: ATGGCTACTGCTGCGTCGT & 161 & XM_018063603.1 \\
\hline & R: TTGAAGGTGGTCTCGTGGAT & & \\
\hline
\end{tabular}

\section{Western blotting}

The primary antibodies were against the following: AMPKa (\#5831, CST Inc., Danvers, MA, USA), phospho-AMPKa (\#2535, CST Inc., p-AMPKa), STK11 (ab199970, Abcam plc., Cambridge, CB, UK), phospho-STK11 (\#3482, CST Inc., p-STK11), PKA (\#4782, CST, Inc.), phospho-PKA (\#9621, CST Inc., p-PKA), TSC2 (\#4308, CST Inc.), phospho-TSC2 (\#3617, CST Inc., p-TSC2), mTOR (\#2792, CST Inc.), and phospho-mTOR (\#2972, CST Inc.; p-mTOR). The reference protein was GAPDH (ab37168, Abcam plc.). The procedure was conducted according to the previous report [33]. The primary antibodies were diluted with $5 \%$ BSA at 1:1000 and incubated overnight at $4^{\circ} \mathrm{C}$. The density of bands was quantified by using the BIO-RAD Gel Doc XR+ (Bio-Rad Laboratories, Hercules, CA, USA) and Image-pro plus 6.0 software (Media Cybernetics, Inc., Rockville, MD, USA), and the relative expression levels were normalized to the reference protein expression level.

\section{Statistical analysis}

The data were analysed using the linear MIXED model of SPSS 19.0 (IBM SPSS, Inc., 2010). The data from dams were tested with the nutritional level as a fixed effect and the initial weight of the dams as a covariate. The data from the offspring were analysed with the nutritional level, litter size and offspring sex as fixed factors. After there are significant differences among fixed factors, the multiple comparison method of SIDAK was applied. The significant difference was set at $P<0.05$, and a significant trend was considered at $0.05 \leq P \leq 0.10$. The results were expressed as the means and standard errors of the means (SEM).

\section{Results}

\section{Carcass weight and blood biochemical indices}

The hot carcass weight of the $\mathrm{R}$ dams was less than that of the $\mathrm{C}$ dams $(P=0.009$, Table 2$)$. The hot carcass weight of the R fetuses was not affected by maternal restriction $(P=0.182)$. The hot carcass weight was less in the $\mathrm{R}$ kids than that in the $\mathrm{C}$ kids $(P=0.017)$. The NEFA concentrations of the $\mathrm{R}$ dams increased $(P=0.007)$. The TP concentrations of R dams and R fetuses decreased $(P<0.05)$. The T4 and T3 concentrations in the dams, fetuses, and kids were not affected by the treatment. The glucagon concentrations were previously reported (27), which increased in the R dams $(P=0.002)$. Sex and litter size affected the TP of the fetuses and kids $(P<0.05)$. The TP concentration of the male fetuses $(28.87 \mathrm{~g} / \mathrm{L})$ were higher $(P=0.045)$ than the females 
$(27.58 \mathrm{~g} / \mathrm{L})$, as well as in kids $(68.37 \mathrm{~g} / \mathrm{L}$ in males vs. $62.89 \mathrm{~g} / \mathrm{L}$ in females, $P=0.009)$. TP concentration of fetuses was decreased $(P=0.007)$ in sequence in singleton $(32.03 \mathrm{~g} / \mathrm{L})$, twins $(27.56 \mathrm{~g} / \mathrm{L})$ and triplets $(25.09 \mathrm{~g} / \mathrm{L})$, while its concentration of kids was lower in twins $(59.81 \mathrm{~g} / \mathrm{L})$ than in singleton $(69.81 \mathrm{~g} / \mathrm{L})$ and triplets $(67.26 \mathrm{~g} / \mathrm{L})$. Litter size affected the glucagon of fetuses $(P=0.018)$, which increased in order in singleton $(31.53 \mathrm{ng} / \mathrm{L})$, twins (32.80 $\mathrm{ng} / \mathrm{L})$ and triplets (39.10 $\mathrm{ng} / \mathrm{L})$.

Table 2

Effects of maternal intake restriction during midgestation on the blood biochemical indices of the pregnant dams, fetuses and kids

\begin{tabular}{|c|c|c|c|c|c|c|c|c|c|c|c|c|c|c|c|c|}
\hline & \multicolumn{4}{|l|}{ Dams $^{1}$} & \multicolumn{3}{|c|}{ Fetuses } & \multicolumn{3}{|c|}{$P$-value } & \multicolumn{3}{|l|}{ Kids } & \multicolumn{3}{|c|}{$P$-value } \\
\hline & $\begin{array}{l}C(n= \\
6)\end{array}$ & $\begin{array}{l}R(n \\
=6)\end{array}$ & SEM & $\begin{array}{l}P \text { - } \\
\text { value }\end{array}$ & $\begin{array}{l}C(n \\
=10)\end{array}$ & $\begin{array}{l}\mathrm{R}(\mathrm{n} \\
=10)\end{array}$ & SEM & Trt & Sex & $\begin{array}{l}\text { Litter } \\
\text { size }\end{array}$ & $\begin{array}{l}C(n \\
=8)\end{array}$ & $\begin{array}{l}\mathrm{R}(\mathrm{n} \\
=8)\end{array}$ & SEM & Trt & Sex & $\begin{array}{l}\text { Litter } \\
\text { size }\end{array}$ \\
\hline $\begin{array}{l}\text { Hot } \\
\text { carcass } \\
\text { weight } \\
(\mathrm{kg})\end{array}$ & 14.7 & 11.0 & 0.78 & 0.009 & 0.65 & 0.58 & 0.037 & 0.18 & 0.71 & 0.54 & 3.9 & 2.9 & 0.25 & 0.017 & 0.46 & 0.78 \\
\hline NEFA & 0.44 & 0.58 & 0.01 & 0.007 & - & - & & & & & - & - & & & & \\
\hline $\mathrm{TP}(\mathrm{g} / \mathrm{L})$ & 74.4 & 66.8 & 2.24 & 0.045 & 29.6 & 26.9 & 0.17 & 0.004 & 0.045 & 0.007 & 64.8 & 66.5 & 1.14 & 0.29 & 0.009 & 0.002 \\
\hline $\begin{array}{l}\text { T4 } \\
\text { (ng/mL) }\end{array}$ & 56.0 & 45.5 & 7.89 & 0.38 & 254.9 & 241.6 & 10.72 & 0.36 & 0.10 & 0.09 & 46.7 & 43.8 & 4.94 & 0.68 & 0.34 & 0.80 \\
\hline $\begin{array}{l}\text { T3 } \\
\text { (ng/mL) }\end{array}$ & 1.4 & 1.3 & 0.17 & 0.49 & 2.0 & 1.9 & 0.10 & 0.50 & 0.28 & 0.64 & 1.1 & 1.3 & 0.06 & 0.18 & 0.85 & 0.71 \\
\hline $\begin{array}{l}\text { Glucagon } \\
(\mathrm{ng} / \mathrm{L})^{2}\end{array}$ & 24.4 & 54.0 & 4.45 & 0.002 & 34.9 & 34.0 & 0.79 & 0.41 & 0.63 & 0.018 & 32.7 & 32.4 & 4.22 & 0.96 & 0.43 & 0.58 \\
\hline \multicolumn{17}{|c|}{$\begin{array}{l}1 \text { Pregnant dams in the control }(C) \text { group were provided } 100 \% \text { of their nutrient requirements. Pregnant dams in the restricted (R) group were provided } \\
60 \% \text { of the intake of the } C \text { group during } 45 \text { to } 100 \mathrm{~d} \text { of gestation and then realimented to } 100 \% \text { of nutrient requirements. }\end{array}$} \\
\hline
\end{tabular}

\section{Blood amino acid profile}

In the R dams (Table 3), the Ser concentration was increased $(P=0.046)$. In the R kids, the concentration of Thr increased $(P=0.011)$. Other detected AAs in the dams and kids were not influenced by treatment $(P>0.05)$. Litter size affected the Val, Met and Tyr concentrations of the kids $(P<0.05)$, which were all higher $(P<0.05)$ in triplets than those in singleton and twins, but sex had no influence $(P>0.05)$ on the AA profile of the kids. 
Table 3

Effects of maternal intake restriction during midgestation on the blood amino acid profile of the pregnant dams and postnatal kids

\begin{tabular}{|c|c|c|c|c|c|c|c|c|c|c|}
\hline \multirow[b]{2}{*}{ Amino acid $(\mu \mathrm{mol} / \mathrm{L})$} & \multicolumn{4}{|l|}{ Dams $^{1}$} & \multicolumn{3}{|l|}{ Kids } & \multicolumn{3}{|c|}{$P$-value } \\
\hline & $C(n=6)$ & $R(n=6)$ & SEM & $P$-value & $C(n=8)$ & $\mathrm{R}(\mathrm{n}=8)$ & SEM & Trt & Sex & Litter size \\
\hline Asp & 28.7 & 26.0 & 3.77 & 0.64 & 43.1 & 51.4 & 5.59 & 0.31 & 0.97 & 0.27 \\
\hline Thr & 54.6 & 63.3 & 5.44 & 0.29 & 82.7 & 113.2 & 7.10 & 0.011 & 0.46 & 0.069 \\
\hline Ser & 82.3 & 103.3 & 6.36 & 0.046 & 96.5 & 107.6 & 6.65 & 0.26 & 0.98 & 0.72 \\
\hline Glu & 108.0 & 126.4 & 9.76 & 0.22 & 171.7 & 177.3 & 10.28 & 0.70 & 0.20 & 0.20 \\
\hline Gly & 1230.5 & 1415.3 & 123.67 & 0.32 & 2505.2 & 2475.5 & 158.77 & 0.90 & 0.30 & 0.29 \\
\hline Ala & 643.1 & 652.9 & 61.76 & 0.91 & 646.4 & 620.6 & 34.19 & 0.59 & 0.43 & 0.42 \\
\hline Val & 287.7 & 243.7 & 26.24 & 0.27 & 429.7 & 467.5 & 27.00 & 0.33 & 0.49 & 0.021 \\
\hline Cys & 17.0 & 33.9 & 11.00 & 0.31 & 90.2 & 49.5 & 16.73 & 0.26 & 0.50 & 0.95 \\
\hline Met & 68.5 & 66.3 & 5.98 & 0.81 & 49.8 & 52.2 & 2.10 & 0.42 & 0.89 & 0.026 \\
\hline Ile & 125.8 & 129.8 & 7.23 & 0.71 & 159.4 & 181.1 & 12.56 & 0.24 & 0.97 & 0.49 \\
\hline Leu & 195.0 & 173.2 & 13.20 & 0.28 & 230.9 & 252.9 & 20.58 & 0.45 & 0.80 & 0.31 \\
\hline Tyr & 102.3 & 103.8 & 9.73 & 0.92 & 82.5 & 81.4 & 6.98 & 0.91 & 0.45 & 0.027 \\
\hline Phe & 77.1 & 68.7 & 7.76 & 0.47 & 72.0 & 75.5 & 5.00 & 0.62 & 0.96 & 0.09 \\
\hline Lys & 249.6 & 252.7 & 26.96 & 0.94 & 293.8 & 336.8 & 36.04 & 0.41 & 0.93 & 0.32 \\
\hline His & 70.2 & 71.4 & 8.95 & 0.93 & 85.5 & 74.3 & 5.88 & 0.20 & 0.36 & 0.81 \\
\hline Arg & 311.4 & 327.8 & 27.81 & 0.69 & 482.8 & 484.6 & 40.55 & 0.97 & 0.79 & 0.20 \\
\hline $\mathrm{EAA}^{2}$ & 1457.0 & 1430.8 & 95.61 & 0.90 & 1976.8 & 2087.7 & 136.81 & 0.50 & 0.96 & 0.22 \\
\hline$N E A A^{2}$ & 2194.8 & 2427.7 & 159.40 & 0.37 & 3545.4 & 3513.7 & 165.98 & 0.90 & 0.56 & 0.45 \\
\hline $\mathrm{BCAA}^{2}$ & 608.6 & 546.6 & 44.10 & 0.36 & 820.0 & 901.5 & 59.22 & 0.34 & 0.83 & 0.12 \\
\hline
\end{tabular}

\section{Glycogen and CAMP in the muscles of offspring}

Maternal restriction did not alter the cAMP and glycogen concentrations in the LT muscles of the offspring (Table 4). Litter size affected $(P=0.006)$ the CAMP concentration of the kids, which was higher $(P<0.05)$ in triplets than those in singleton and twins. Sex and litter size did not influence $(P>0.05)$ the cAMP and glycogen levels of the fetuses.

Table 4

Effects of maternal intake restriction during midgestation on the cAMP and glycogen concentrations in the Longissimus thoracis of the offspring

\begin{tabular}{|c|c|c|c|c|c|c|c|c|c|c|c|c|}
\hline \multirow[b]{2}{*}{ Compound } & \multicolumn{3}{|c|}{ Fetuses } & \multicolumn{3}{|c|}{$P$-value } & \multicolumn{3}{|l|}{ Kids } & \multicolumn{3}{|c|}{$P$-value } \\
\hline & $\begin{array}{l}C(n= \\
10)\end{array}$ & $\begin{array}{l}R(n= \\
10)\end{array}$ & SEM & Trt & Sex & $\begin{array}{l}\text { Litter } \\
\text { size }\end{array}$ & $\begin{array}{l}C(n= \\
8)\end{array}$ & $\begin{array}{l}R(n= \\
8)\end{array}$ & SEM & Trt & Sex & $\begin{array}{l}\text { Litter } \\
\text { size }\end{array}$ \\
\hline cAMP (nmol/g protein) & 1.68 & 1.65 & 0.600 & 0.97 & 0.87 & 0.13 & 15.17 & 8.86 & 2.928 & 0.17 & 0.059 & 0.006 \\
\hline $\begin{array}{l}\text { Glycogen }(\mathrm{mg} / \mathrm{g} \\
\text { protein) }\end{array}$ & 0.43 & 0.46 & 0.017 & 0.21 & 0.74 & 0.50 & 0.26 & 0.29 & 0.012 & 0.20 & 0.20 & 0.28 \\
\hline
\end{tabular}

\section{The mRNA and protein expression of the energy metabolism-related genes in the LT muscles}


The mRNA expression of $A C O X 1, N R 1 H 3, G R$ and $P R K A B 1$ in the LT muscles of $\mathrm{R}$ dams was upregulated $(P<0.05$, Fig. 1A), while the $P C K 2 \mathrm{mRNA}$ tended to be decreased $(P=0.075)$. The expression of AMPKa and STK11 proteins in the R dams was not affected $(P>0.05$, Fig. 1B).

Maternal intake restriction upregulated the fetal PGC1A mRNA $(P=0.018$, Fig. $2 A)$ and tended to increase the fetal $A C O X 1 \mathrm{mRNA}(P<0.10)$. The expression of NR1H3 mRNA was downregulated in the R kids $(P<0.05$, Fig. 2B), but the ACOX1 mRNA in the R kids tended to be increased $(P=0.092)$. Sex and litter size did not affect the mRNA expression of these detected genes in the fetuses $(P>0.05)$. Sex affected $(P<0.05)$ the mRNA expression of $P C K 1$ and PRKAB1 in the kids, while litter size had no effect $(P>0.05)$ on the mRNA expression of these genes. Maternal intake restriction tended to increase $(P$ $<0.10)$ the p-STK11 protein abundance in the fetuses, and the ratio of p-STK11/STK11 tended to increase $(P<0.10)$ in the restricted fetuses and kids $($ Fig 2C and D). The p-AMPKa and AMPKa protein expression of the R fetuses and R kids were not affected $(P>0.05)$. Litter size affected the $\mathrm{p}$-AMPKa/AMPKa level in the fetuses $(P=0.028)$, which was lower in triplets than those in singleton and twins. Sex had no effect $(P>0.05)$ on the protein expression in the offspring.

Maternal intake restriction reduced the CREB1, CREBBP and PKA mRNA expression in the fetuses $(P<0.05$, Fig. 3A). The expression of $C R E B B P$ and $P K A$ mRNA were downregulated in the R kids $(P<0.05$, Fig. 3B), and the $C R E B 1$ mRNA in the R kids tended to be reduced $(P=0.099)$. The expression of the pPKA and PKA proteins in both the fetuses and kids was downregulated $(P<0.05$, Fig. $3 \mathrm{C}$ and $\mathrm{D})$ by maternal intake restriction. Litter size affected the pPKA protein expression in the kids $(P=0.019)$, which was lower in singleton than those in twins and triplets. Sex had no effect $(P>0.05)$ on the protein expression in the offspring.

\section{The mRNA expression of circadian CLOCK pathway genes in the LT muscles}

Maternal intake restriction reduced the fetal BMAL1 mRNA expression $(P=0.043$, Table 5), tended to reduce $(P=0.051)$ the fetal $C R Y 2 \mathrm{mRNA}$ level, and tended to increase $(P=0.068)$ the fetal $D B P$ mRNA level. Maternal intake restriction decreased $(P=0.049)$ the $D B P$ mRNA expression but increased $(P=$ $0.019)$ the $C L O C K$ mRNA expression in the kids. Litter size affected the BMAL 1 mRNA expression in the kids $(P=0.023)$, which was higher in triplets than that in twins. Sex had no influence $(P>0.05)$ on the mRNA expression of these circadian genes in the fetuses and kids.

Table 5

Effects of maternal intake restriction during midgestation on the mRNA expression of circadian genes in the Longissimus thoracis muscles of the offspring

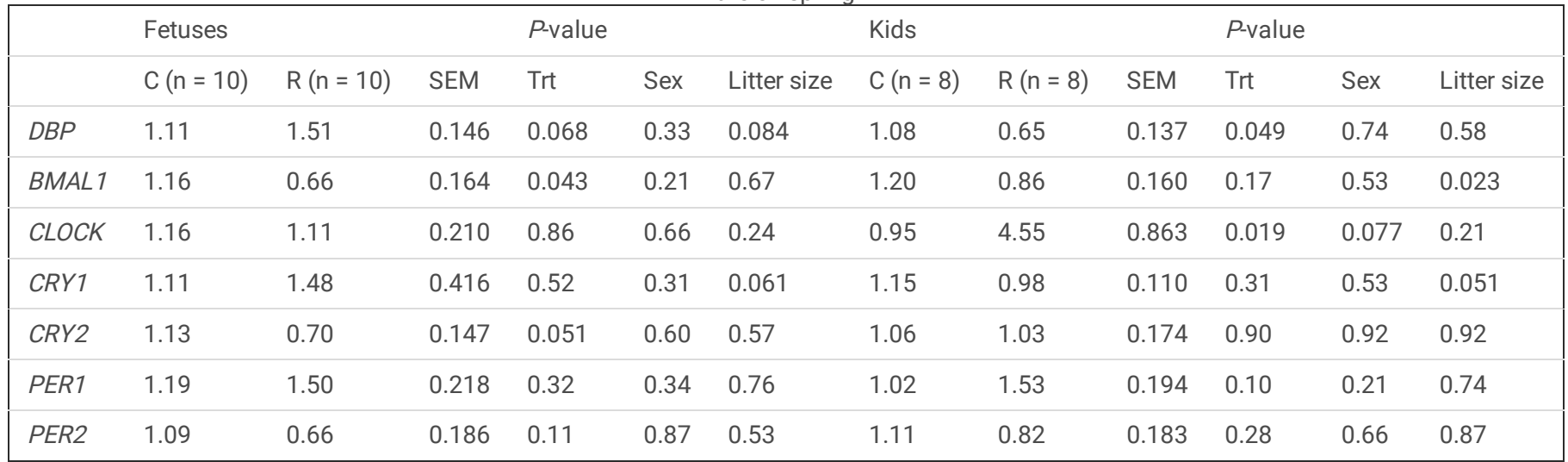

\section{The mRNA and protein expression of the mTOR pathway}

Maternal intake restriction downregulated $(P<0.05$, Fig. 3A) the AKT1, mTOR, and RPTOR mRNA expression in the LT muscles of the fetuses and upregulated $(P=0.049)$ the fetal TSC2 mRNA expression. Maternal intake restriction upregulated $(P=0.01$, Fig. 3B $)$ the mRNA expression of TSC2 in the kids and tended to increase $(P=0.069)$ the mRNA expression of TSC1. Sex and litter size did not affect $(P>0.05)$ the mRNA expression of the above genes in the fetuses and kids.

Maternal intake restriction reduced $(P<0.05$, Fig. 3C and 3D) the protein expression of mTOR and p-mTOR in the LT muscles of the fetuses and kids. The protein expression of p-TSC2 and the ratio of p-TSC2/TSC2 in the R kids tended to be upregulated $(P<0.10)$, while the ratio of p-mTOR/mTOR tended to be decreased $(P=0.095)$. Sex affected $(P=0.019)$ fetal p-mTOR protein expression, litter size affected $(P<0.05)$ fetal mTOR and p-mTOR/mTOR expression, fetal mTOR level in the triplets was higher $(P=0.017)$ than those in the singleton and twins, while fetal $\mathrm{p}-\mathrm{mTOR} / \mathrm{mTOR}$ in the singleton was higher $(P=0.014)$ than those in the twins and triplets. Sex also affected $(P=0.046)$ the mTOR protein expression in the kids, which were higher in the female kids than that in the males. Litter size affected $(P<0.05)$ the expression of mTOR and p-mTOR, and they were both lower in the triplets than those in the singleton, while they were intermediate in the twins.

\section{Discussion}


Food deprivation in humans and mammals is common in underdeveloped areas, and nutrient restriction during gestation programs the muscle development and metabolism of the offspring $(3,8)$, but the mechanism remains unclear. In the present study, the $40 \%$ intake restriction reduced the carcass weight of dams and kids, and reduced the plasma TP contents of dams and fetuses. Maternal malnutrition did not affect the cAMP and glycogen contents of the offspring muscles, while the mRNA expression of genes associated with fatty acid oxidation and regulation in the mother and offspring were upregulated, and the mRNA and protein expression of genes involved in the mTOR pathway in offspring were downregulated. Moreover, the mRNA expression of the CLOCK pathway was affected in offspring.

Intake restriction reduced the hot carcass weight of the dams, indicating that the maternal muscle mass declined. The TP concentrations in the maternal and fetal plasma was reduced, whereas the venous AA profile of dams and kids, the AA profile in the umbilical cord blood of fetal goats that was reported previously (33), and the glucose and insulin concentrations that we have reported (27) were not affected. These results suggest an insufficient supply of protein in the dams and fetuses. However, the $40 \%$ maternal restriction did not reduce the weight and birth weight of the fetuses, while the body weight and carcass weight of the kids after birth were reduced (28). These results suggest in utero maternal compensation and defective muscle growth and development programming after birth.

ACOX1 is the first rate-limiting enzyme of fatty acid $\beta$-oxidation, which catalyzes acyl-CoA into 2-trans-enoyl-CoA. NR1H3 (also known as LXRa) regulates fat homeostasis and plays an important role in cholesterol metabolism and lipid synthesis $(35,36)$. Glucocorticoid receptor (GR) is associated with the stress response caused by a high level of cortisol under starvation, which is a common target regulator of intrauterine metabolic programming (37). PRKAB1 is a regulatory subunit in the AMPK protein complex that monitors cellular energy status (38). The increase in the blood NEFA concentration and the $A C O X 1, N R 1 H 3, G R$ and PRKAB1 mRNA expression in the restricted dams indicated the change in lipid metabolism and the upregulation of fatty acid oxidation in the LT muscle. PCK2 in muscle tissues acts to catalyze the conversion of oxaloacetate into phosphoenolpyruvate, by which the oxaloacetate availability of the tricarboxylic acid (TCA) cycle and glucose homeostasis are regulated (39). Downregulation of PCK2 mRNA in muscle implied the reduced glucose availability in the muscle tissue and the downregulated TCA cycle oxidation-energy pathways. Therefore, intake restriction probably resulted in the stimulation of fatty acid oxidation and the suppression of glucose oxidative degradation in the LT muscles of the dams.

As one of the target organs for intrauterine metabolic programming $(3,40)$, muscle tissue is involved in blood glucose uptake and clearance and the regulation of glucose and lipid metabolism homeostasis. In our study, maternal restriction did not alter the cAMP and glycogen concentrations of LT muscles in the offspring. The mRNA expression of G6PD, PCK1, PCK1, PRKAA2 and PRAKB1 and the protein expression of AMPKa in the offspring were also unaffected in our study. These results were in line with the findings in lambs after $50 \%$ intrauterine restriction during early to midgestation (21). We speculated that $40 \%$ maternal intake restriction during midgestation did not alter the glucose storage capacity and consumption in the LT muscles of the fetuses and kids. However, maternal intake restriction increased the mRNA expression of ACOX1 in the LT muscles of the fetuses and kids, and these results were consistent with the mRNA expression of $A C O X 1$ in the dams. Moreover, the mRNA expression of PGC1A in the fetuses and the protein expression of p-STK11/STK11 in the fetuses and kids were upregulated, while the NR1H3 mRNA expression was downregulated in the kids. PGC1A promotes mitochondrial oxidative metabolism (41), while p-STK11 stimulates the phosphorylation of ACOX1 (42) and inhibits fat synthesis. The increase in the ACOX1 and PGC1A mRNA and the p-STK11/STK11 protein in the restricted fetuses and kids indicate that maternal restriction upregulated the lipolysis of muscle tissue and fatty acid $\beta$-oxidation as an energy source. Similarly, a $40 \%$ maternal feed restriction also upregulated the mRNA expression of PGC1A in the LT muscles of fetal calves during mid- to late gestation (43).

Maternal restriction simultaneously reduced the mRNA expression of CREB1 and CREBBP in both the fetuses and kids. Recent studies have found that CREB interacts with PGC1A, NR1H3 and DBP to regulate glucose synthesis, gluconeogenesis (30), and fat metabolism (44) in mouse livers. CREB also alters the main clock in the supraoptic nucleus of mice by phosphorylation at Ser133 (31), while CREB expression is regulated by the rhythm clock genes to maintain metabolic rhythms. Study in the mouse muscle had revealed that knockout of the rhythmic gene BMAL 1 leads to disturbances in the transcription of glucose, fat and protein metabolism-related genes (45). Consistent with the change in the CREB and CREBBP regulators in the offspring of this study, maternal restriction had a tendency to increase $D B P$ mRNA in the fetal muscle, while the $D B P$ mRNA expression was decreased in the kids. Moreover, maternal restriction reduced the mRNA expression of BMAL 1 and $C R Y 2$ in the fetuses, while the mRNA expression of CLOCK was increased in the kids. In the rhythmic CLOCK signaling pathway, DBP activates the transcription of PER, while PER inhibits the expression of CLOCK and BMAL1 by forming a dimer with CRY (46). The mRNA expression patterns of DBP, BMAL1 and CLOCK in the fetuses and kids in this study were consistent with the CLOCK signaling transmission pathway. Of note, CLOCK plays a role in histone acetylation (47), and this epigenetic mechanism is closely related to developmental programming. We proposed that maternal intake restriction programmed the CREB-CREBBP regulatory factors to alter the mRNA expression of energy metabolism and the CLOCK pathway in the offspring.

The AKT-TSC-mTORC1 signaling pathway is one of the main regulators of muscle protein synthesis, which occurs in response to cellular energy, AA, insulin and insulin-like growth factor 1 (IGF1) signals $(15,48)$. Maternal restriction downregulated the mRNA expression of AKT1, $m T O R$ and RPTOR and the protein expression of mTOR and p-mTOR in the LT muscles of fetuses, but the mRNA expression of TSC2 was upregulated. The expression of TSC1 and TSC2 mRNA and p-TSC2 protein in the LT muscles of kids was upregulated by maternal restriction, while the protein expression of mTOR and p-mTOR was downregulated. These results showed that maternal restriction altered mTOR pathway signaling in both the fetuses and kids. Similarly, a decrease in the p-mTOR protein of the fetal LT muscle was observed under $50 \%$ maternal restriction during early to midgestation (21). Since the TP level was decreased, while the blood glucose, insulin, IGF1 (27), and muscular glycogen levels in the offspring of the present study were unaffected, the reason may be ascribed to the reduction in the overall protein or AA supply under intake restriction when energy is deficient. A previous study in intrauterine growth restricted (IUGR) sheep has shown that AA perfusion reduces the rate of protein degradation and increases protein deposition by $150 \%$, and the AA level independently regulates mTOR pathway signaling (49). In addition to energy, $40 \%$ maternal intake restriction may aggravate the lack of protein and AAs, 
leading to the downregulation of the mTOR pathway in offspring, which affects muscle tissue protein synthesis and muscle mass. Moreover, recent studies found that rhythmic per protein regulates the mTORC1 signaling pathway by recruiting TSC1 in the mouse (32), while the rhythmic factor BMAL1 is also tightly linked to mTOR pathway protein synthesis via S6K (50). These findings are consistent with the change in the CLOCK and mTOR pathways in this study; and these results suggest the connection among intrauterine malnutrition, rhythm disruption, and protein synthesis in the skeletal muscles of the offspring.

Furthermore, both the mRNA and protein expression levels of PKA were decreased in the offspring from the restricted group in this study. CREB is located downstream of the PKA factor (51), and PKA phosphorylates raptor to regulate mTORC1 (52). It is reasonable to conclude that maternal intake restriction alters the PKA-CREB pathway to regulate energy metabolism, CLOCK signaling and protein synthesis and leads to metabolic programming in the LT muscles of the offspring. The classical pathway for the regulation of glucose metabolism under energy-deficient conditions is the glucagon-cAMP-PKA pathway (29). Elevated glucagon caused by intake restriction in dams was observed, but the cAMP and glycogen concentrations in the LT muscles of offspring were not altered. Intermediate mediators between the high level of maternal glucagon and the downstream PKA-CREB pathway need to be identified.

The effects of sex and litter size on the phenotype and metabolism of the skeletal muscles of mammals has been reported (53-56). In this study, the effects of litter size on blood and tissue metabolites, and genes expression of offspring were also observed, such as TP, glucagon, Val, Met, Tyr and cAMP concentrations, and mTOR protein expression. Intake restriction of dams apparently leads to a more severe protein deficiency in triplets than those of singleton and twins. Sex also influenced the blood TP concentration and mTOR (or p-mTOR) protein expression in offspring. The effects of sex and litter size on protein metabolism in the IUGR offspring need further investigation.

\section{Conclusions}

Using the goat model in this study, maternal 60\% energy-protein undernutrition upregulated the expression of genes involved in PKA-CREB and mTOR signals, downregulated the ACOX1 mRNA expression, and affected the CLOCK pathway in the LT muscles of nutrition-restricted fetuses and kids consistently. We inferred that maternal intake restriction during midgestation programmed the PKA-CREB pathway in the skeletal muscle of offspring to upregulate fat oxidation, downregulate protein synthesis, and alter the circadian clock. These results reveal the role of the PKA-CREB pathway in metabolic programming in the skeletal muscles of offspring exposed to intrauterine malnutrition, which deepened our understanding of the molecular mechanism of metabolic adaptation in skeletal muscle caused by maternal undernutrition in humans and mammals.

\section{Abbreviations}

ACACA = acetyl-CoA carboxylase alpha; $\mathrm{ACOX1}$ = acyl-CoA oxidase 1; $\mathrm{ACTG1}=$ actin gamma $1 ; \mathrm{AKT} 1$ = protein kinase $\mathrm{B} ; \mathrm{AMPKa}=\mathrm{AMP}-\mathrm{activated}$ protein kinase alpha; BMAL1 = aryl hydrocarbon receptor nuclear translocator-like protein 1; CLOCK = clock circadian regulator; CPT1A = carnitine palmitoyltransferase $1 \mathrm{~A} ; \mathrm{CREB} 1=\mathrm{cAMP}$-responsive element-binding protein 1; $\mathrm{CREBBP}=\mathrm{CREB}$-binding protein; $\mathrm{CRY} 1=\mathrm{cryptochrome} 1 ; \mathrm{CRY} 2=$ cryptochrome 2; DBP = D-box binding PAR bZIP transcription factor; G6PC = glucose-6-phosphatase catalytic subunit; G6PDH = glucose-6-phosphate dehydrogenase; GR = glucocorticoid receptor; INSR = insulin receptor; $\mathrm{mTOR}=$ mammalian target of rapamycin; NR1 H3 = nuclear receptor subfamily 1 group $\mathrm{H}$ member 3 ; PCK1 = phosphoenolpyruvate carboxykinase $1 ; \mathrm{PCK} 2$ = phosphoenolpyruvate carboxykinase 2, mitochondrial; $\mathrm{PER} 1$ = Period $1 ; \mathrm{PER} 2$ = Period 2; PGC1 a = peroxisome proliferator-activated receptor gamma coactivator 1 alpha; PKA = protein kinase A; PRKAA2 = protein kinase AMP-activated catalytic subunit alpha 2; PRKAB1 = protein kinase AMP-activated noncatalytic subunit beta 1; RPTOR = regulatory-associated protein of $\mathrm{mTOR}$; $\mathrm{STK} 11$ = serine-threonine kinase 11 ; TSC1 = tuberous sclerosis $1 ;$ TSC2 = tuberous sclerosis 2.

\section{Declarations}

\section{Ethics approval and consent to participate}

All the protocols used in this study were approved by the Animal Care Committee according to the Animal Care and the Use Guidelines of the Institute of Subtropical Agriculture, Chinese Academy of Sciences, Changsha, China (No. KYNEAAM-2015-0009).

\section{Consent for publication}

Not applicable.

\section{Availability of data and material}

The datasets supporting the conclusions of this article are included within the article.

\section{Competing interests}

The authors declare that they have no competing interests. 


\section{Funding}

This work was supported by the National Natural Science Foundation of China [31730092, 31760678 and 31402105]; State Key Project of Research and Development Plan [2018YFD0501900]; and Hunan innovative Province construction project [2019RS3021].

\section{Authors' contributions}

XZ conducted the experiments, analyzed the data and wrote the paper; QY designed the study and revised the manuscript; HY collected the data; Ao Ren: assisted with animal experiments; $\mathrm{ZH}$ analyzed the data and revised the manuscript; $\mathrm{ZT}$ acquired funding and revised the manuscript.

\section{Acknowledgements}

The authors thanked Shaoxun Tang for the instruction of data analysis, and appreciated Xuefeng Han for the aid in WB detection.

\section{References}

1. Hochberg Z, Feil R, Constancia M, Fraga M, Junien C, Carel JC, et al. Child health, developmental plasticity, and epigenetic programming. Endocr Rev. 2011;32(2):159-224.

2. Batool R, Butt MS, Sultan MT, Saeed F, Naz R. Protein-Energy Malnutrition: A Risk Factor for Various Ailments. Crit Rev Food Sci Nutr. 2015;55(2):24253.

3. Beauchamp B, Harper ME. In utero Undernutrition Programs Skeletal and Cardiac Muscle Metabolism. Front Physiol. $2015 ; 6: 401$.

4. Gonzalez JM, Camacho LE, Ebarb SM, Swanson KC, Vonnahme KA, Stelzleni AM, et al. Realimentation of nutrient restricted pregnant beef cows supports compensatory fetal muscle growth. J Anim Sci. 2013;91(10):4797-806.

5. Sen U, Sirin E, Ensoy U, Aksoy Y, Ulutas Z, Kuran M. The effect of maternal nutrition level during mid-gestation on postnatal muscle fibre composition and meat quality in lambs. Anim Prod Sci. 2016;56(5):834-43.

6. Mohrhauser DA, Taylor AR, Gonda MG, Underwood KR, Pritchard RH, Wertz-Lutz AE, et al. The influence of maternal energy status during midgestation on beef offspring tenderness, muscle characteristics, and gene expression. Meat Sci. 2015;110:201-11.

7. Zhu MJ, Ford SP, Means WJ, Hess BW, Nathanielsz PW, Du M. Maternal nutrient restriction affects properties of skeletal muscle in offspring. J Physiol. 2006;575(Pt 1):241-50.

8. Brown LD, Hay WW, Jr. Impact of placental insufficiency on fetal skeletal muscle growth. Mol Cell Endocrinol. 2016;435:69-77.

9. Hales CN, Barker DJ. The thrifty phenotype hypothesis. Br Med Bull. 2001;60:5-20.

10. Ozanne SE. Metabolic programming-knowns, unknowns and possibilities. Nature Reviews Endocrinology. 2014;11:67-8.

11. Saxton RA, Sabatini DM. mTOR Signaling in Growth, Metabolism, and Disease. Cell. 2017;168(6):960-76.

12. Yoon MS. mTOR as a Key Regulator in Maintaining Skeletal Muscle Mass. Front Physiol. 2017;8:788.

13. Hardie DG. Sensing of energy and nutrients by AMP-activated protein kinase. Am J Clin Nutr. 2011;93(4):891S-6.

14. Cui X, Yao L, Yang X, Gao Y, Fang F, Zhang J, et al. SIRT6 regulates metabolic homeostasis in skeletal muscle through activation of AMPK. Am J Physiol Endocrinol Metab. 2017;313(4):E493-E505.

15. Hart B, Morgan E, Alejandro E. Nutrient Sensor Signaling Pathways and Cellular Stress in Fetal Growth Restriction. J Mol Endocrinol. 2019;62(2):R155-R65.

16. Zhang EE, Liu Y, Dentin R, Pongsawakul PY, Liu AC, Hirota T, et al. Cryptochrome mediates circadian regulation of cAMP signaling and hepatic gluconeogenesis. Nat Med. 2010;16:1152.

17. Eckel-Mahan KL, Patel VR, Mohney RP, Vignola KS, Baldi P, Sassone-Corsi P. Coordination of the transcriptome and metabolome by the circadian clock. Proc Natl Acad Sci U S A. 2012;109(14):5541-6.

18. Reinke H, Asher G. Crosstalk between metabolism and circadian clocks. Nature Reviews Molecular Cell Biology. 2019;20(4):227-41.

19. Stenvers DJ, Scheer FAJL, Schrauwen P, la Fleur SE, Kalsbeek A. Circadian clocks and insulin resistance. Nature Reviews Endocrinology. 2019;15(2):75-89.

20. He ZX, Sun ZH, Beauchemin KA, Yang WZ, Tang SX, Zhou CS, et al. Effect of protein or energy restriction during late gestation on hormonal and metabolic status in pregnant goats and postnatal male offspring. Animal. 2015;9(11):1843-51.

21. Zhu MJ, Ford SP, Nathanielsz PW, Du M. Effect of maternal nutrient restriction in sheep on the development of fetal skeletal muscle. Biol Reprod. 2004;71(6):1968-73.

22. Lie S, Morrison JL, Williams-Wyss O, Suter CM, Humphreys DT, Ozanne SE, et al. Impact of periconceptional and preimplantation undernutrition on factors regulating myogenesis and protein synthesis in muscle of singleton and twin fetal sheep. Physiological reports. 2015;3(8):e12495.

23. Zhu MJ, Han B, Tong J, Ma C, Kimzey JM, Underwood KR, et al. AMP-activated protein kinase signalling pathways are down regulated and skeletal muscle development impaired in fetuses of obese, over-nourished sheep. J Physiol. 2008;586(10):2651-64.

Page $11 / 16$ 
24. Boyle KE, Patinkin ZW, Shapiro ALB, Bader C, Vanderlinden L, Kechris K, et al. Maternal obesity alters fatty acid oxidation, AMPK activity, and associated DNA methylation in mesenchymal stem cells from human infants. Molecular metabolism. 2017;6(11):1503-16.

25. Mendonca JE, Vilela MC, Bittencourt H, Lapa RM, Oliveira FG, Alessio ML, et al. GFAP expression in astrocytes of suprachiasmatic nucleus and medial preoptic area are differentially affected by malnutrition during rat brain development. Nutr Neurosci. 2004;7(4):223-34.

26. Vilela MC, Mendonca JE, Bittencourt H, Lapa RM, Alessio ML, Costa MS, et al. Differential vulnerability of the rat retina, suprachiasmatic nucleus and intergeniculate leaflet to malnutrition induced during brain development. Brain Res Bull. 2005;64(5):395-408.

27. Zhou X, Yang H, Yan Q, Ren A, Kong Z, Tang S, et al. Evidence for liver energy metabolism programming in offspring subjected to intrauterine undernutrition during midgestation. Nutr Metab (Lond). 2019;16(1):20.

28. Zhou X, Yan Q, Yang H, Ren A, Kong Z, Tang S, et al. Effects of Maternal Undernutrition during Mid-Gestation on the Yield, Quality and Composition of Kid Meat Under an Extensive Management System. Animals. 2019;9(4):173.

29. Goldstein I, Hager GL. The Three Ds of Transcription Activation by Glucagon: Direct, Delayed, and Dynamic. Endocrinology. 2018;159(1):206-16.

30. Kim H, Zheng Z, Walker PD, Kapatos G, Zhang K. CREBH Maintains Circadian Glucose Homeostasis by Regulating Hepatic Glycogenolysis and Gluconeogenesis. Mol Cell Biol. 2017;37(14):e00048-17.

31. Wheaton KL, Hansen KF, Aten S, Sullivan KA, Yoon H, Hoyt KR, et al. The Phosphorylation of CREB at Serine 133 Is a Key Event for Circadian Clock Timing and Entrainment in the Suprachiasmatic Nucleus. J Biol Rhythms. 2018;33(5):497-514.

32. Wu R, Dang F, Li P, Wang P, Xu Q, Liu Z, et al. The Circadian Protein Period2 Suppresses mTORC1 Activity via Recruiting Tsc1 to mTORC1 Complex. Cell Metab. 2019;29(3):653-67.

33. Chen W, Yan Q, Yang H, Zhou X, Tan Z. Effects of restrictions on maternal feed intake on the immune indexes of umbilical cord blood and liver Toll-like receptor signaling pathways in fetal goats during pregnancy. Journal of Animal Science and Biotechnology. 2019;10(1):29.

34. Livak KJ, Schmittgen TD. Analysis of relative gene expression data using real-time quantitative PCR and the 2- $\triangle \Delta C T$ method. Methods. 2001;25(4):402-8.

35. Bełtowski J. Liver X Receptors (LXR) as Therapeutic Targets in Dyslipidemia. Cardiovasc Ther. 2008;26(4):297-316.

36. Cha J-Y, Repa JJ. The Liver X Receptor (LXR) and Hepatic Lipogenesis: the carbohydrate-response element-binding protein is a target gene of LXR. J Biol Chem. 2007;282(1):743-51.

37. Chadio S, Kotsampasi B, Taka S, Liandris E, Papadopoulos N, Plakokefalos E. Epigenetic changes of hepatic glucocorticoid receptor in sheep male offspring undernourished in utero. Reprod Fertil Dev. 2017;29(10):1995-2004.

38. Lin SC, Hardie DG. AMPK: Sensing Glucose as well as Cellular Energy Status. Cell Metab. 2018;27(2):299-313.

39. Stark R, Kibbey RG. The mitochondrial isoform of phosphoenolpyruvate carboxykinase (PEPCK-M) and glucose homeostasis: has it been overlooked? Biochim Biophys Acta. 2014;1840(4):1313-30.

40. Sharples AP, Stewart CE, Seaborne RA. Does skeletal muscle have an 'epi'-memory? The role of epigenetics in nutritional programming, metabolic disease, aging and exercise. Aging Cell. 2016;15(4):603-16.

41. Supruniuk E, Mikłosz A, Chabowski A. The Implication of PGC-1a on Fatty Acid Transport across Plasma and Mitochondrial Membranes in the Insulin Sensitive Tissues. Front Physiol. 2017;8:923.

42. Willows R, Sanders MJ, Xiao B, Patel BR, Martin SR, Read J, et al. Phosphorylation of AMPK by upstream kinases is required for activity in mammalian cells. Biochem J. 2017;474(17):3059-73.

43. Paradis F, Wood KM, Swanson KC, Miller SP, McBride BW, Fitzsimmons C. Maternal nutrient restriction in mid-to-late gestation influences fetal mRNA expression in muscle tissues in beef cattle. BMC Genomics. 2017;18(1):632-

44. Zheng Z, Kim H, Qiu Y, Chen X, Mendez R, Dandekar A, et al. CREBH Couples Circadian Clock With Hepatic Lipid Metabolism. Diabetes. 2016;65(11):3369-83.

45. Dyar KA, Hubert MJ, Mir AA, Ciciliot S, Lutter D, Greulich F, et al. Transcriptional programming of lipid and amino acid metabolism by the skeletal muscle circadian clock. PLoS Biol. 2018;16(8):e2005886.

46. Hamilton EE, Kay SA. SnapShot: Circadian Clock Proteins. Cell. 2008;135:368-e1.

47. Grimaldi B, Nakahata Y, Kaluzova M, Masubuchi S, Sassone-Corsi P. Chromatin remodeling, metabolism and circadian clocks: the interplay of CLOCK and SIRT1. The international journal of biochemistry \& cell biology. 2009;41(1):81-6.

48. Luo Y, Xu W, Li G, Cui W. Weighing In on mTOR Complex 2 Signaling: The Expanding Role in Cell Metabolism. Oxid Med Cell Longev. 2018;2018:7838647.

49. Brown LD, Rozance PJ, Thorn SR, Friedman JE, Hay WW, Jr. Acute supplementation of amino acids increases net protein accretion in IUGR fetal sheep. American journal of physiology Endocrinology and metabolism. 2012;303(3):E352-E64.

50. Khapre RV, Kondratova AA, Patel S, Dubrovsky Y, Wrobel M, Antoch MP, et al. BMAL1-dependent regulation of the mTOR signaling pathway delays aging. Aging. 2014;6(1):48-57.

51. Delghandi MP, Johannessen M, Moens U. The cAMP signalling pathway activates CREB through PKA, p38 and MSK1 in NIH 3 T3 cells. Cell Signal. 2005;17(11):1343-51.

52. Jewell JL, Fu V, Hong AW, Yu F-X, Meng D, Melick CH, et al. GPCR signaling inhibits mTORC1 via PKA phosphorylation of Raptor. eLife. $2019 ; 8$.

Page $12 / 16$ 
53. Zhong T, Jin PF, Dong EN, Li L, Wang LJ, Zhang HP. Caprine sex affects skeletal muscle profile and MRFs expression during postnatal development. Anim Sci J. 2013;84(5):442-8.

54. Tsiplakou E, Papadomichelakis G, Sparaggis D, Sotirakoglou K, Georgiadou M, Zervas G. The effect of maternal or artificial milk, age and sex on three muscles fatty acid profile of Damascus breed goat kids. Livest Sci. 2016;188:142-52.

55. Dearden L, Bouret SG, Ozanne SE. Sex and gender differences in developmental programming of metabolism. Molecular Metabolism. 2018;15:8-19.

56. Symonds ME, Budge H. Nutritional models of the developmental programming of adult health and disease: Workshop on 'Nutritional models of the developmental origins of adult health and disease'. Proc Nutr Soc. 2009;68(2):173-8.

\section{Figures}

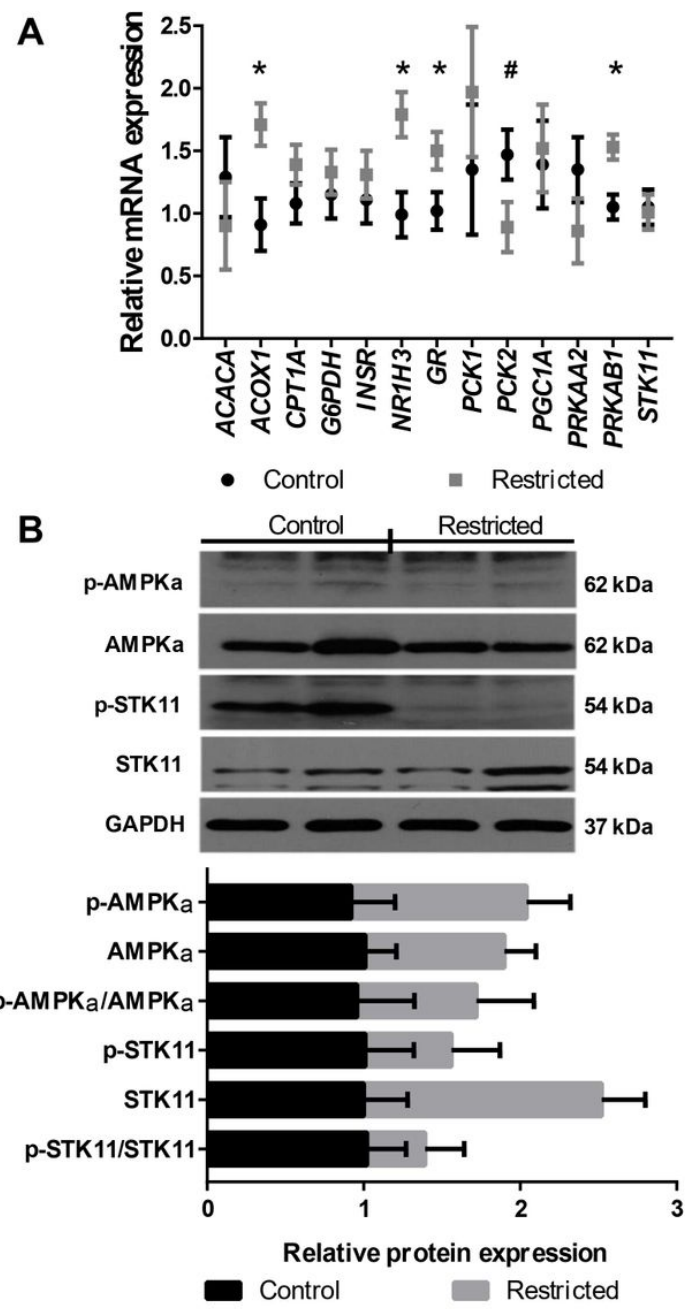

Figure 1

The mRNA (A) and protein expression (B) of energy metabolism-related genes in the Longissimus thoracis muscles of the dams $(n=6)$. ${ }^{P}<0.05$ and $\# 0.05 \leq P<0.10$ for the effect of treatment. 
A

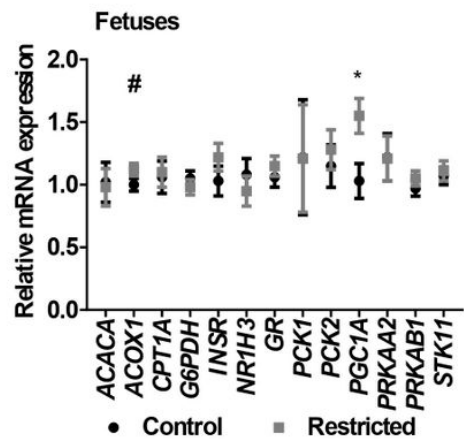

C

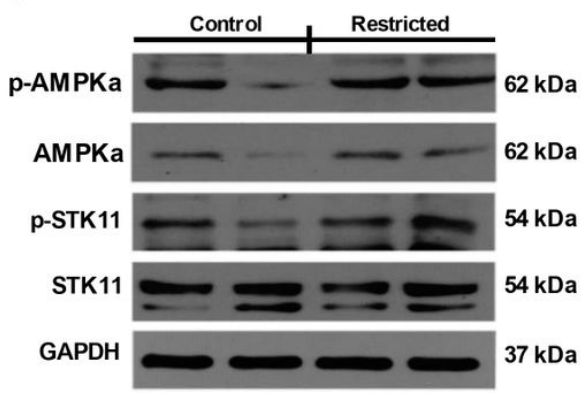

Fetuses
B

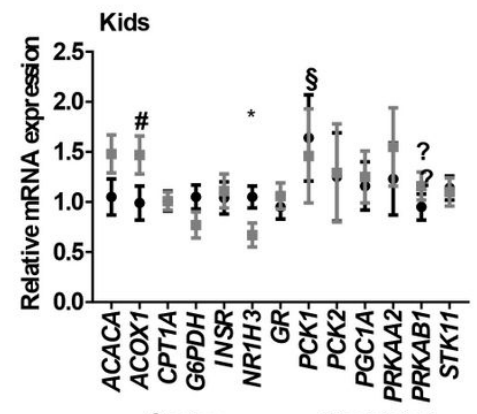

D

- Contro

- Restricted

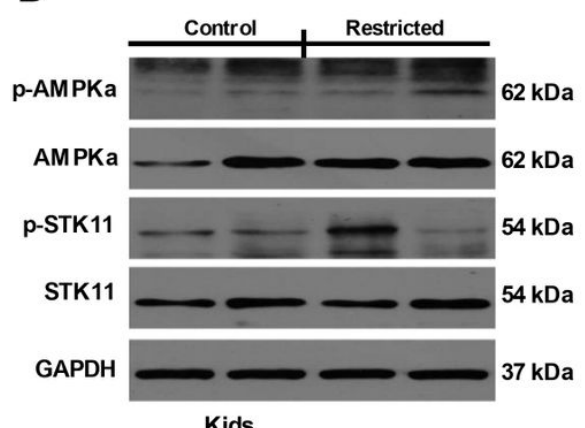

Kids

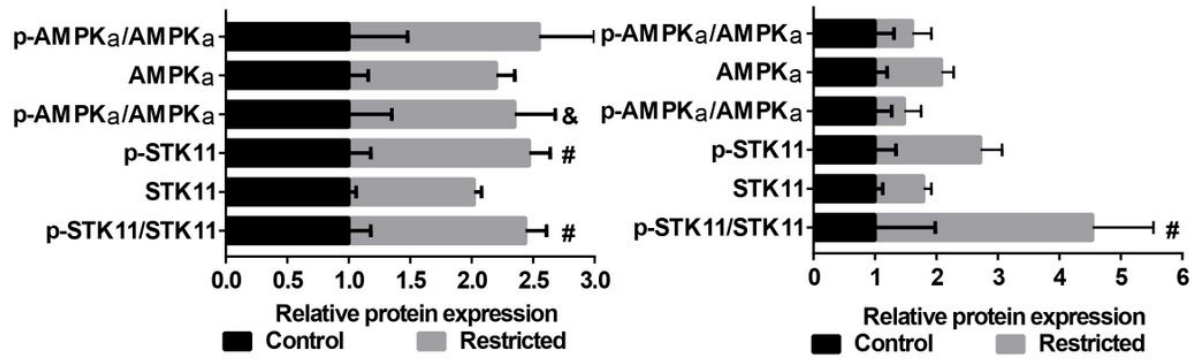

Figure 2

The expression of energy metabolism-related genes in the Longissimus thoracis muscles of the offspring. A) mRNA expression in the fetuses $(n=10) ; B)$ mRNA expression in the kids $(n=8)$; C) protein expression in the fetuses $(n=10)$; $D)$ protein expression in the kids $(n=8)$. *P<0.05 and \#0.05 $P<0.10$ for the effect of treatment; $\S \mathrm{P}<0.05$ for the effect of sex; \&P $<0.05$ for the effect of litter size. 
A

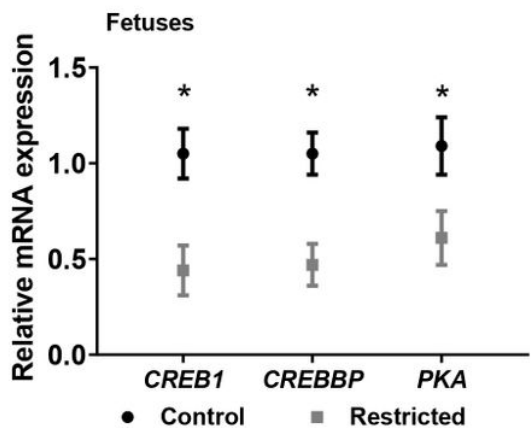

C
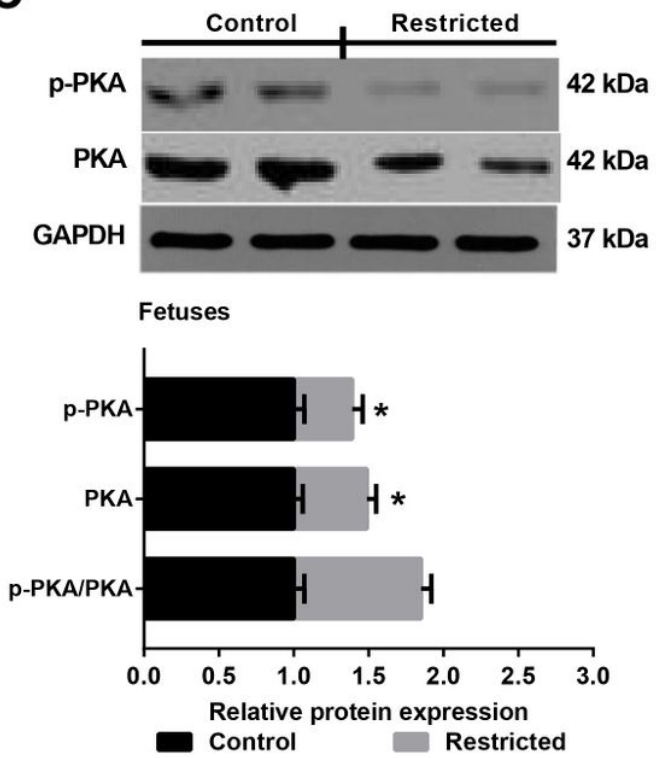

B
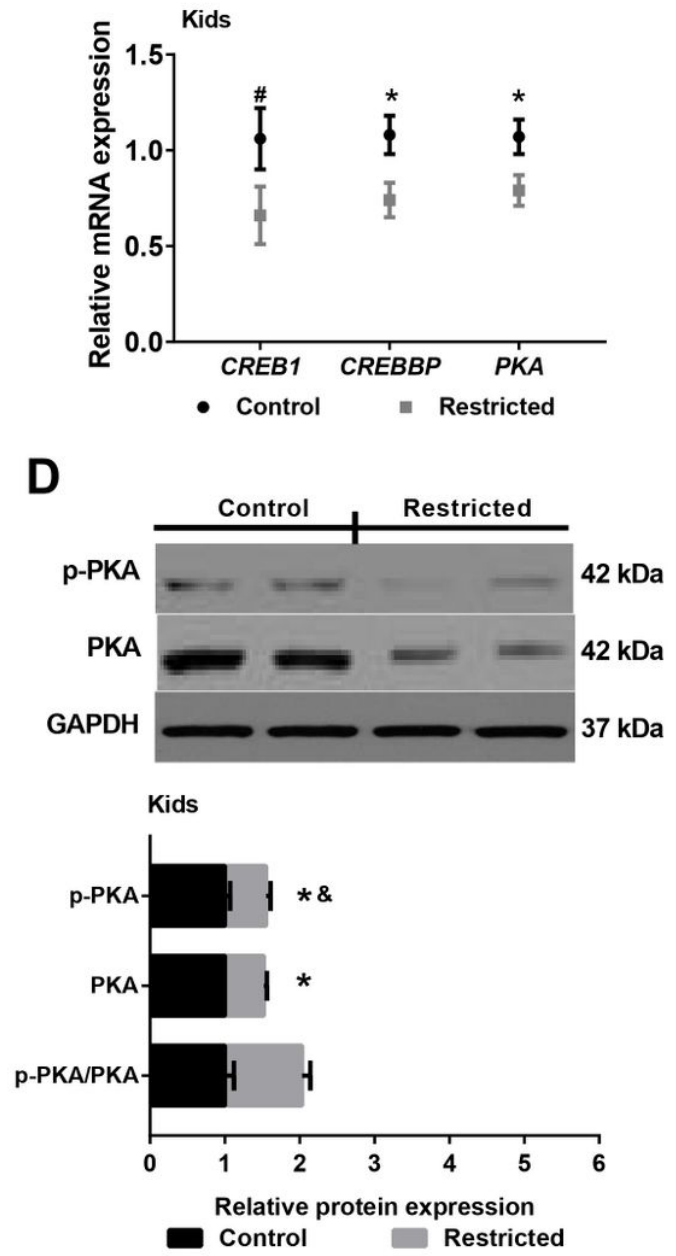

Figure 3

The expression of PKA and CREB genes in the Longissimus thoracis muscles of the offspring. A) mRNA expression in the fetuses ( $n=10)$; $B)$ mRNA expression in the kids $(n=8) ; C)$ protein expression in the fetuses $(n=10)$; $)$ protein expression in the kids $(n=8)$. ${ }^{*}<0.05$ and $\# 0.05 \leq P<0.10$ for the effect of treatment; §P $<0.05$ for the effect of sex; \&P $<0.05$ for the effect of litter size. 
A

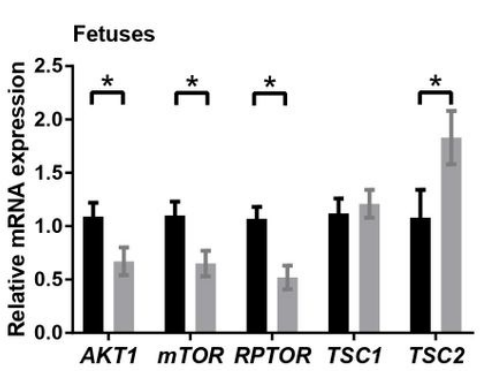

C

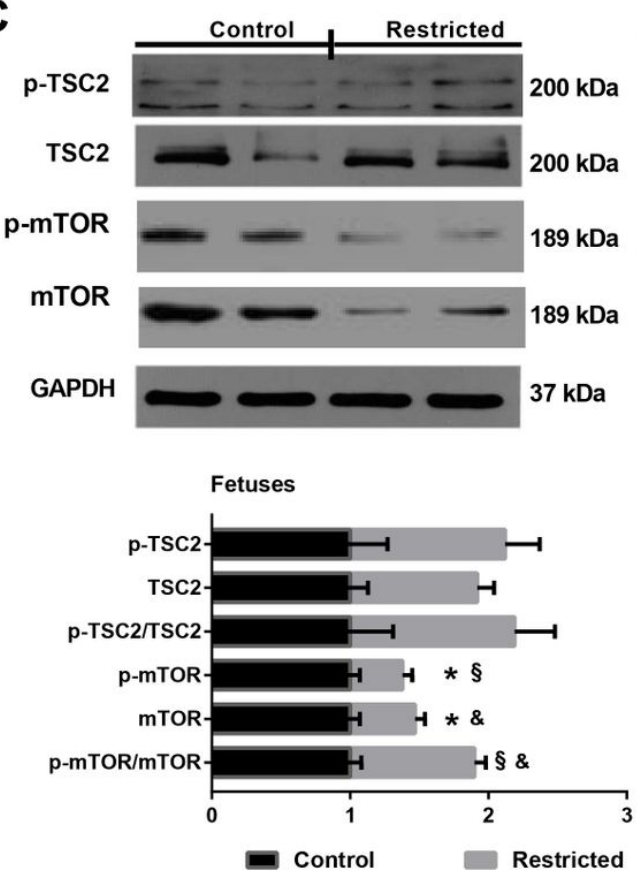

B

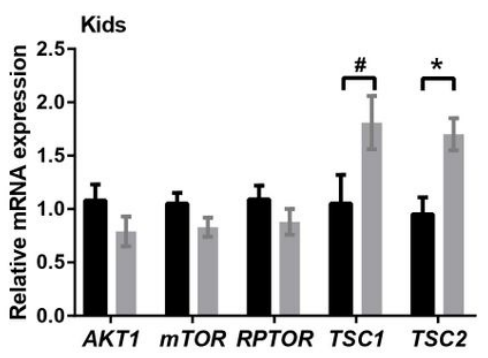

D

p-TSC

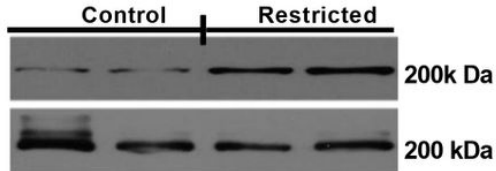

p-mTOR

mTOR

GAPDH
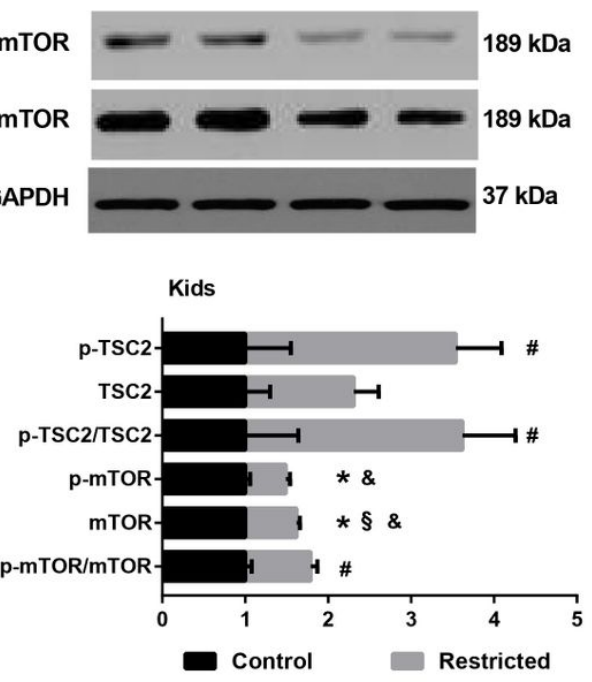

Figure 4

The expression of mTOR signaling genes in the Longissimus thoracis muscles of the offspring. A) mRNA expression in the fetuses ( $n=10)$; $B$ ) mRNA expression in the kids $(n=8) ; C)$ protein expression in the fetuses $(n=10)$; $)$ protein expression in the kids $(n=8)$. ${ }^{*}<0.05$ and $\# 0.05 \leq P<0.10$ for the effect of treatment; §P $<0.05$ for the effect of sex; \&P $<0.05$ for the effect of litter size. 